\title{
QUANTUM MERUIT
}

\section{G.H.L. FRIDMAN}

This article analyzes the theoretical and practical differences between contractual and restitutionary quantum meruit Instances of quasi-contractual meruit are also considered. The author explores the evolution and historical foundations for these various claims. While claims for restitutionary quantum meruit are well established today, the scope and range of relief as well as the theoretical basis upon which these claims are invoked, remain undecided. Factors for a successful claim of restitutionary quantum meruit include the intention to be compensated or reimbursed, having not acted gratuitously, and the existence of a special relationship. While recovery was thought to be dependent on whether the defendant receives a benefit, the author explains that this is not always crucial. An examination of Justice McLachlin's judgment in the Peel case concludes the author's article.
L'auteur analyse les différences théoriques et pratiques existant entre le quantum meruit contractuel et aux fins de restitution. Plusieurs actions concernant les quasi-contrats sont également considérées. $L$ 'auteur explore lévolution et les fondements historiques de ces diverses réclamations. Bien que les poursuites en restitution de la valeur de services rendus soient bien établies aujourd'hui, la portée et la gamme des mesures de redressement et les fondement théoriques de ces poursuites restent incertains. Les facteurs d'une poursuite en restitution sur la base du quantum meruit incluent l'intention d'être indemnisé ou remboursé, le fait de n'avoir pas agi à titre gratuit et lëtendue de rapports de confiance. Alors que le recouvrement semble dépendre de l'avantage reçu par le défendeur, l'auteur explique que ce n'est pas impératif. Il conclut par un examen de la décision du juge McLachlin dans la cause Peel.

\section{TABLE OF CONTENTS}

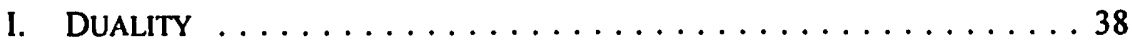

II. Historical Foundations $\ldots \ldots \ldots \ldots \ldots \ldots \ldots \ldots \ldots$

III. A MODERN APPROACH $\ldots \ldots \ldots \ldots \ldots \ldots \ldots \ldots \ldots \ldots$

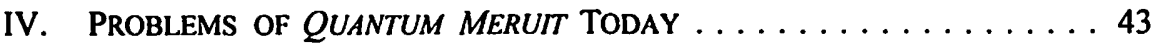

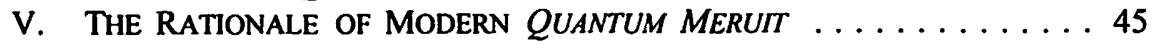

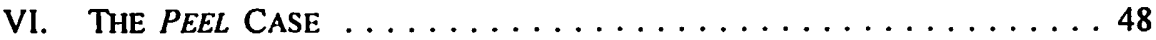

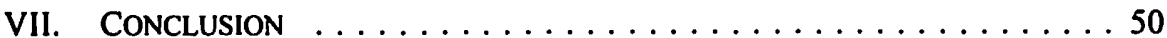

\section{Duality}

The expression quantum meruit refers to the fact that the plaintiff is seeking not a precise sum of money, nor a sum representing the general damages incurred by the plaintiff as a consequence of some wrongful act on the part of the defendant, but a sum that will provide the plaintiff with the value of what the plaintiff has done for the defendant, usually calculated in terms of the market price or value of those services.'

Q.C., F.R.S.C., Professor Emeritus, Faculty of Law, University of Westem Ontario.

But see J.W. Carter, "Ineffective Transactions," in P.D. Finn, ed., Essays on Restitution (North Ryde, N.S.W.: Law Books Co., 1990) 206 at 235-40, and S.M. Waddams, "Restitution for the Part Performer," in J. Swan \& B. Reiter, eds., Studies in Contract Law (Toronto: Butterworths, 1980) 151 , for discussion of some problems associated with determining the amount to be awarded in certain situations.

Where the claim is in respect of goods delivered to the defendant by the plaintiff, the claim is quantum valebant, a distinction or refinement that came about in the latter half of the seventeenth century: Boult v. Harris (1676), 3 Keb. 469 (K.B.); Webb v. Moore (1691), 2 Vent. 279 (K.B.); 
Today it is clear that a quantum meruit claim may be either contractual ${ }^{2}$ or restitutionary, ${ }^{3}$ i.e. what used to be termed quasi-contractual, in character. Quantum meruit has two distinct connotations; and for practical, as well as theoretical reasons it is necessary to differentiate them. Failure to do so may result in misunderstanding the distinction between contractual liability on the one hand and restitutionary liability on the other, a distinction that is vital to the proper invocation and application of the law of restitution, as well as to the appreciation of the true nature and scope of the law of restitution.

Two examples, one from England the other from Canada, illustrate the difference between contractual and restitutionary quantum meruit. In William Lacey (Hounslow) Lld. v. Davis ${ }^{4}$ the plaintiffs rendered services to the defendant at the latter's request in anticipation of a building contract that failed to materialize. When the plaintiffs sued for payment for the services, the defendant argued that it was the common expectation of the parties that a contract would be entered into between them and that the plaintiffs' services would be rewarded by the profits of the contract. The defendant denied that in the circumstances there was any implied promise to pay for the services in issue. The defendant's argument was that any quantum meruit claim was necessarily contractual and any such claim was negated by the fact that the parties had an express contract in mind thereby making it impossible to imply any other, contradictory contract. This argument was rejected. Instead the court explained that quantum meruit, though contractual in origin, had given rise to another form of action founded upon what was known, in 1957 when the case was being determined, as quasi-contract. In such quasicontractual instances of the application of quantum meruit the court looked at the facts and ascertained from them whether or not a promise to pay should be implied, irrespective of the actual views or intentions of the parties at the time when the work was done and the services rendered. ${ }^{5}$

Burns Fry Ltd. v. Khurana ${ }^{6}$ involved both a contractual and a restitutionary claim by the plaintiffs based upon their acts as agents for the defendant in the sale of a business. An agreed fee was payable upon the closing of the transaction. After the plaintiffs had found a purchaser willing to pay approximately the price asked for the

C.H.S. Fifoot, History and Sources of the Common Law; Tort and Contract (London: Stevens \& Son, 1949) at 361, note 18 [hereinafter Fifoot].

As in $J \& J$ Penner Construction Ltd. v. Cringan (1994), 93 Man. R. (2d) 252 (Q.B.) where the situation was governed by a contract between the parties but they had not fixed on a price for the services rendered by the plaintiffs. Cp. Campbell, Albow, Low Lid. v. Black (1996), 26 O.R. (3d) (Gen. Div.) 111; and, possibly, Westview Holdings Lid. v. Mowbray (1992), 94 Sask. R. 263 (Q.B.).

3 As it would have been in Capital Construction \& Foundation Lid. v. Cote (1993), 124 N.B.R. (2d) 204 (T.D.) [hereinafter Capital Construction], if the defendant had obtained anything of value from the work done by the plaintiffs, which was not the case.

$4 \quad$ [1957] I W.L.R. 932.

s lbid. at 936. With this contrast Magical Waters Fountains Led. v. Sarnia (City) (1992), 91 D.L.R. (4th) 760 (Ont. Div. Ct.) [hereinafter Magical], where the quantum meruit claim was unsuccessful because no work done by the plaintiffs exceeded what was usually involved in tendering or making a proposal.

6 (1985), 20 D.L.R. (4th) 245 (Ont. H.C.J.). 
business by the defendant, the latter changed his mind and decided not to sell. Krever J. rejected both claims. The defendant had acted in good faith and was not in breach of any implied term of the contract. ${ }^{7}$ Nor was the alternative of restitution, i.e. quasicontract, applicable. The nature of the contract was such that the plaintiffs had taken the risk of not being paid if there was no sale and no substantial benefit had been acquired by the plaintiff. ${ }^{8}$

It is evident from even a cursory examination of these cases that the basis upon which a quantum meruit claim can be advanced and be successful is different where such a claim is contractual from where it is quasi-contractual or restitutionary. The explanation for this is to be found in the history of such claims.

\section{Historical Foundations}

According to Sir William Holdsworth it was in the seventeenth century that there first appeared the idea that when a promise to pay could be implied the writ of assumpsit could be used to claim quantum meruit. . $^{9}$ This development stemmed from the way that the writ of indebitatus assumpsit was finally accepted in Slade's Case. ${ }^{10}$ In Holdsworth's view, in making this logical application of Slade's Case it is probable that the common law courts were influenced by the fact that the Court of Chancery gave a remedy in such cases, i.e., those concerning innkeepers, tailors, carriers, factors, bailiffs, vendors of goods and subsequently, in the eighteenth century, sureties who had paid off the principal debt and sought to recover that payment from the original debtor. He also referred to other instances involving accounts stated and the enforcement of an award by an arbitrator ordering one of the parties to an arbitration to perform a specific act.

Fifoot, however, suggested that there was a debate over the issue whether this action upon a quantum meruit was a particular application of indebitatus assumpsit or a distinct species of assumpsit. If the first it would be the particular application of Slade's Case that Holdsworth indicated: if the latter it would not be connected with Slade's Case but would be an individual type of assumpsit, from which both the modern general law of contract and the concept of quantum meruit evolved. According to Fifoot, despite some suggestions to the contrary in the latter part of the seventeenth century, by the first half of the eighteenth century professional opinion had hardened in favour of the view that quantum meruit was an individual type of assumpsit."

7 Unlike the party which decided not to go through with the contract arranged by the agent in Alpha Trading Ltd. v. Dunnshaw-Patten Ltd., [1981] Q.B. 290, on which see G.H.L. Fridman, The Law of Agency, 7th ed. (London: Butterworths, 1996) at 197-98.

Cp. Capital Construction, supra note 3.

Sir W.S. Holdsworth, A History of English Law, vol. 3, 5th ed. (London, Methuen: Sweet \& Maxwell, 1942) at 446-47, citing Warbrooke v. Griffin (1610), 2 Brownl. 254 (C.P.). See also the Six Carpenters Case (1610), 8 Co. Rep. 146a (K.B.). In this he followed J.B. Ames, Lectures on Legal History and Miscellaneous Legal Essays (Cambridge, Mass.: Harvard University Press, 1913) at 154.

"Fifoot, supra note 1 at $360-63$. 
Thus Holdsworth and Fifoot disagree as to the origins and nature of this novel seventeenth century form of action. It would be wrong to dismiss this as a mere academic debate of no consequence or importance to modern lawyers. A connection between quantum meruit and indebitatus assumpsit would give the former a stronger contractual flavour, and, in consequence, might entitle modern lawyers to say that the use of quantum meruit in a non-contractual context, to provide a claim in the absence of any valid, operative and enforceable contract was neither historically nor logically justified. Evolution from the original writ of assumpsit, on the other hand, would be more rational. If such were the case, it could be reasoned that assumpsit, ultimately or eventually, led to two important developments in the common law. The first would be the emergence of a law of contract via the medium of indebitatus assumpsit and its offshoots. The second would be the evolution of a law of restitution, distinct from contract though its roots may have been the same as those of the law of contract. It is only necessary to refer to and think about the historical confusion present in the speeches in Sinclair v. Brougham, ${ }^{12}$ especially that of Viscount Haldane, and the judgments in the High Court of Australia in Pavey \& Matthews Pty Ltd. v. Paul,,$^{13}$ to realize how important it is to get history straight and not to make mistakes about the origins of modern law.

\section{A MODERN APPROACH}

The underlying distinction between contractual and non-contractual, or restitutionary, quantum meruit was appreciated by Sir Percy Winfield. In both The Province of the Law of Tort ${ }^{14}$ and his later work, Law of Quasi-Contracts ${ }^{15}$ he adverted to the distinction. But his discussion of quantum meruit, and in particular its relevance in the law of restitution, altered in the period between the appearance of these two works.

In the earlier book he stated that quantum meruit had been described as a source of the law of quasi-contract: but it was also a source of considerable misapprehension since, inter alia, quantum meruit had several applications some of which had nothing to do with true quasi-contract. In support of this he set out three distinct uses of the term quantum meruit, all of which were contractual, not quasi-contractual, in nature. These were (a) where one party had broken a contract and the other was claiming reasonable remuneration for what had been done under the contract; (b) as a means of redress on a new contract that by implication had replaced an earlier one; and (c) where a contract did not fix a price or remuneration for work done.

These three categories of quantum meruit recovery have been considered by later authorities, sometimes with contradictory conclusions. The second and third categories were also cited as examples of the application of quantum meruit as a purely

[1914] A.C. 398 (H.L.).

(1987), 162 C.L.R. 221 (H.C. of A.): criticized as to the history employed therein by Carter, supra note 1 .

P. Winfield, Province of the Law of Tort (Cambridge: Cambridge University Press, 1931) at 15760.

P. Winfield, Law of Quasi-Contracts (London: Sweet \& Maxwell, 1952) at 51-60. 
contractual action by Cheshire, Fifoot and Fursmton. ${ }^{16}$ However the case of the broken contract has caused more controversy.

Winfield suggested that if the victim of the breach did not sue for breach of contract but elected to treat the contract as at an end and sue for quantum meruit, the plaintiff's remedy would be quasi-contractual. This seems to be denied by Goff and Jones." They are also dubious about the existence of authority for the possibility of the election of remedies mentioned by Winfield. Given their general propositions for the existence of a restitutionary claim, ${ }^{18}$ in particular the need for a request for services and the receipt by the defendant of a tangible benefit, they would appear to be on firm ground in negating the quasi-contractual or restitutionary character of the relief given in the leading case of Planche v. Colburn, ${ }^{19}$ the case that is relied on by Winfield as authority for his proposition about the election of a remedy. Goff and Jones are also critical $^{20}$ of the decision in the New Zealand case of Lodder v. Slowey, ${ }^{21}$ a case which is referred to, seemingly with approval, in a recent Canadian work. ${ }^{22}$ In that case the victim of a breach of contract was held able to sue for the value of the work performed up to the time of the breach. The analysis of the Canadian authors, unlike that of the English ones, seems to be in terms of restitution not contract, which accords with the view of Winfield.

Cheshire, Fifoot and Furmston ${ }^{23}$ agree with the view of Winfield, despite the arguments of Goff and Jones, with respect to the first of Winfield's categories, i.e., that a claim based on an election to treat a broken contract at an end would be quasicontractual not contractual in character. On the other hand, if the plaintiff is seeking what have been called "reliance" damages, or possibly what have been called "restitutionary" damages, in contrast with what have been called "expectation" damages, ${ }^{24}$ the plaintiff's claim would seem to be based on breach of contract not restitution. Hence it might be necessary to differentiate a claim for payment for services rendered up to the moment of breach from a claim for reimbursement of moneys expended on the plaintiff's efforts to prepare for performance of the plaintiff's obligations under the contract. The latter would be a contractual claim, as in the Australian case of Commonwealth of Australia v. Amann Aviation Pty Ltd. ${ }^{25}$ The former would appear to be a quasi-contractual or restitutionary action belonging to the categories of restitutionary quantum meruit in modern times.

G. Cheshire, C. Fifoot \& M. Furmston, Law of Contract, 13th ed. (London: Butterworths, 1996) at 685-87.

R. Goff \& G. Jones, The Law of Restitution, 4th ed. (London: Sweet \& Maxwell, 1993) at 426, note 35 .

Ibid. at 424-28.

(1831), 8 Bing. 14 (C.P.).

Supra note 17 at 25 , note 31 .

(1902), 20 N.Z.L.R. 321 (A.C.) aff d [1904] A.C. 442 (P.C.).

P.D. Maddaugh \& J.D. McCamus, Law of Restitution (Aurora, Ont.: Canada Law Book, 1990) at 427.

Supra note 16 at 685 .

L.L. Fuller \& W.R. Perdue Jr., "The Reliance Interest in Contract Damages" (1939) 46 Yale L.J. 373.

(1991), 174 C.L.R. 64. 
This brings us to Winfield's later book, Law of Quasi-Contracts, in which he gave five distinct senses in which quantum meruit was used. The first three were those originally stated in The Province of the Law of Torts, i.e. the contractual senses or uses considered above. The final two were purely quasi-contractual, viz., (a) where the plaintiff had done work under a contract that was void $a b$ initio because it failed to satisfy some legal requirement; and (b) where a contract was unenforceable owing to non-compliance with the Statute of Frauds. ${ }^{26}$ In the years since Winfield's Law of Quasi-Contracts appeared, in 1952, much has happened notably, but not exclusively, in Canada. However, the distinction drawn by Winfield between the contractual and quasi-contractual uses or senses of quantum meruit is even more valid today than it was in 1952. Furthermore Winfield's statement in 1931, in The Province of the Law of Tort, that quantum meruit was a source of quasi-contract may be said to have particular relevance in Canada, because of the seminal decision of the Supreme Court in Deglman v. Guaranty Trust Co. of Canada, ${ }^{27}$ which involved a contract that was unenforceable because it was not in writing or evidenced in writing as required, at that time, by the Statute of Frauds. The court gave the plaintiff a quantum meruit award that was quasicontractual in nature and, in the process, gave a head start to the ultimate recognition and subsequent evolution of the law of restitution in Canada. ${ }^{28}$

\section{Problems of Quantum Meruit TOday}

Quantum meruit claims can still be contractual: of that there is no doubt. But quantum meruit claims play a more important role in the modern law of restitution by providing the basis for recovery in a number of situations where a claim in contract is inapplicable and cannot be maintained, yet the plaintiff is deserving of relief in respect of work performed or services rendered by the plaintiff to, or for the benefit of, the defendant. Although these instances of restitutionary quantum meruit recovery are wellestablished, at least in some jurisdictions, two aspects of such situations remain undecided.

The first is the scope or range of this relief. Although the list of such situations has grown since Winfield wrote in 1952, it is too early to state that the list is closed. In the words of Morden J., as he then was, in James More \& Sons v. University of Ottawa: "Just as the categories of negligence are never closed, neither can those of restitution."29 In Canada, in consequence of how the law of restitution has evolved and developed, ${ }^{30}$ it appears to be open to the courts to invoke quasi-contractual or

Statute of Frauds, (1677) (U.K.) 29 Char. Il, c. 3.

[1954] S.C.R. 725.

On which see W. Angus, "Restitution in Canada since the Deglman Case" (1964) 42 Can. Bar Rev. 529; G.H.L. Fridman, "The Foundations of Restitution: A Canadian Perspective" (1989) 19 West. Aust. L.R. 131; G.H.L. Fridman, "The Reach of Restitution" (1991) 11 Legal Studies 304 [hereinafter Fridman, "The Reach of Restitution"]; G.H.L. Fridman, Restitution, 2d ed. (Toronto: Carswell, 1992) at 12-19 [hereinafter Fridman]; and Maddaugh \& McCamus, supra note 22. (1975), 49 D.L.R. (3d) 666 at 676.

The development of restitution in England and Australia does not seem to have gone as far as in Canada: although recent English and Australian decisions, which do not fall to be examined here, indicate that the courts in those jurisdictions are slowly, but perhaps inexorably, moving towards 
restitutionary quantum meruit whenever they consider that, in the interests of a just and fair result, it is imperative to provide the plaintiff with some form of recovery as against the defendant in the absence of a contract between the parties and despite the fact that the defendant has committed no tort against the plaintiff. Restitution is a useful weapon in the armoury of the law. ${ }^{31}$

The second issue, which is even more controversial, concerns the theoretical basis upon which restitutionary quantum meruit may be invoked and relied on to provide a remedy. It is in this context that may be found, bandied about by academic writers, such expressions as "free acceptance," "incontrovertible benefit" and "irrebuttable benefit." ${ }^{32}$ Those who use these terms are not on firm ground, in the sense that they are basing their theories on what can be discovered in the case law. ${ }^{33}$ However it is necessary for present purposes to consider these terms, unsupported by judicial language though they are, as well as other pertinent expressions, in order to understand what has been happening in the courts in recent years.

Judges have been searching for some acceptable basis on which to hold a plaintiff deserving of success, some way of differentiating a legitimate, allowable claim from one without valid juridical foundation. The fact that the plaintiff has done certain things and thereby incurred expense or employed valuable time and effort is not enough to justify a claim for reimbursement or recompense. The classic statements of English judges in the nineteenth century testify to their unwillingness to grant a remedy solely on the basis of work done or services rendered. To have done so would have undermined the law of contract. Hence such remarks as those of Bowen L.J. in Falcke v. Scottish Imperial Insurance $\mathrm{Co}^{34}$ that "liabilities are not forced upon people behind their backs any more than you can confer a benefit upon a man against his will" and the earlier comment by C.B. Pollock in Taylor v. Laird: "one cleans another's shoes; what can the other do but put them on?" These statements continue to haunt English, Canadian, Australian and New Zealand judges in the twentieth century. Fortunately, it may be argued they have not been permitted to stand in the way of the development of the law. In this respect some judges seem to have adopted and followed the famous

the Canadian position.

Cp. Pettkus v. Becker (1981), 117 D.L.R. (3d) 257 at 273 (Dickson C.J.) [hereinafter Pettkus].

Supra note 19 at 12-26; P. Birks, An Introduction to the Law of Restitution (New York: Clarendon Press, 1989) at 265-93; A. Burrows, "Free Acceptance and the Law of Restitution" (1988) 104 L.Q. Rev. 576; G. Mead, "Free Acceptance: Some Further Considerations" (1989) 105 L.Q. Rev. at 460; M. Garner, "The Role of Subjective Benefit in the Law of Unjust Enrichment" (1990) 10 Ox. J.L.S. 42; P. Birks, "In Defence of Free Acceptance" in A. Burrows, ed., Essays in the Law of Restitution (Oxford: Clarendon Press, 1991) 105; G.H. Jones, "Restitutionary Claims for Services Rendered" (1977) 93 L.Q. Rev. 273; G.H. Jones, "Claims Arising out of Anticipated Contracts which do not Materialize" 18 U.W.O.L. Rev. 447; J. Beatson, "Benefit, Reliance and the Structure of Unjust Enrichment" (1987) 40 Curr. Leg. Probs. 71; M. McInnes, "Incontrovertible Benefits and the Canadian Law of Restitution" (1991) 12 Ad. Q. 323. adopting it as a basis for her decision, in Peel (Regional Municipality) v. Canada; Peel (Regional Municipality) v. Ontario (1993), 98 D.L.R. (4th) 140 at $158-63$ (S.C.C.) [hereinafter Peel]. 
remark of Lord Atkin in United Australia Ltd. v. Barclays Bank, ${ }^{36}$ to the effect that judges should not allow the ghosts of the past to stand in the way of progress, even if and when they appear clanking their medieval chains.

This has undoubtedly been true of Canadian judges who, since the Deglman case, have enthusiastically, even cavalierly, invoked the doctrine of restitutionary quantum meruit in a variety of instances. ${ }^{37}$ In the present context it is unnecessary to rehearse the details of these instances of recovery. Suffice it to say that Canadian judges do not appear to have been hampered by precedent or principle in their search for ways to compensate deserving plaintiffs. Nor do they seem to be as concerned as English academics about the proper terminology to employ to explain the whys and wherefores of their use of quantum meruit in such circumstances. Indeed, as discussed elsewhere, ${ }^{38}$ they have gone beyond quantum meruit and have given some plaintiffs proprietary remedies in situations which, in the beginning, gave rise only to a claim for monetary compensation. In such instances the medieval idea of quantum meruit has travelled a long way from its origins.

However, in the majority of the instances where restitutionary quantum meruit is permitted, the result remains the award of a sum of money to the plaintiff. What must now be considered is the extent to which Canadian judges have theorized on the appropriate way to distinguish valid from invalid claims.

\section{The Rationale of MOdERN QUANTUM MERUIT}

The quest is for the common bond or bonds, if any, between such instances of restitutionary quantum meruit recovery as for services rendered in anticipation of a contract that never materializes, or under an illegal, void, broken or unenforceable contract, or in the belief that the one providing the services would be rewarded in the other party's testament, or for services given in consequence or pursuance of a matrimonial or quasi-matrimonial relationship between cohabiting parties. At first sight there appears to be little that links these diverse situations other than the fact that one party has done something for the other in the absence of any contractual relationship that can be recognized and enforced by the courts. On further examination, however, there is more.

In the first place underlying these variegated sets of circumstances is a theme that can also be found in cases where a plaintiff has been allowed to recover money paid to a third party on behalf of the defendant, in order to discharge the defendant's liability to such third party. ${ }^{39}$ As explained in the English case of Owen v. Tate ${ }^{40}$ the vital issue is whether the plaintiff acted "officiously." One way of establishing whether

[1941] A.C. 1 at $28-29$ (H.L.).

On which see Fridman, supra note 28 at 300-49; also see Fuller \& Perdue, supra note 24 at 307 481.

Fridman, "The Reach of Restitution," supra note 28.

The leading Canadian case is now Peel, supra note 33, where the claims were unsuccessful because the payments in question did not discharge any legal liability of the defendants.

[1976] I Q.B. 402 (C.A.). 
or not the plaintiff did act officiously is to determine whether what was done was done out of the goodness of the plaintiff's heart, by reason of a moral impulse, for the plaintiff's own purposes or under some legal compulsion. ${ }^{41}$ Similarly, where restitutionary quantum meruit recovery is involved, it is necessary to determine whether the plaintiff acted for selfish, personal reasons, without any initial request from the defendant and in the absence of any tacit understanding that the services or work were not to be performed gratuitously or speculatively or were performed in the belief or on the understanding that the defendant was going to recompense or reimburse the plaintiff.

This is implicit, if not explicit, in the Deglman case. It was made even clearer by the Ontario Court of Appeal in Nicholson v. St. Denis. ${ }^{42}$ There it was held that to permit recovery where work had been done in the absence of a contract between plaintiff and defendant the plaintiff had to establish first knowledge of the benefit that was conferred by the plaintiff's acts and secondly either an express or implied request by the defendant for that benefit or the defendant's acquiescence in performance of the work. As evidenced by that case, and later ones, three factors are important.

The first is the intention of the plaintiff to be compensated or reimbursed and not to be acting gratuitously. In a commercial, as contrasted with a familial or matrimonial case, it may be more easily concluded that the plaintiff never intended that the work or services should go unrewarded. ${ }^{43}$ But this is not always so. One who submits a plan for a competition to design a building, hoping to win and so obtain the contract, may simply be speculating not revealing any intention to be paid save by the ultimate reward of the contract should it come about. So, too, one who tenders for a construction contract does not expect payment for the work involved in drawing up the tender. ${ }^{44}$ The intended reward is the contract to undertake the construction. ${ }^{45}$ In contrast in a non-commercial case the gratuitous nature of the services may more easily be concluded. Here, too, however, that conclusion may not be justified. Where a man and woman are cohabiting, as husband and wife or otherwise, and the woman works in the man's business, this may be treated as part and parcel of the familial relationship. But

Cp. Brooks Wharf and Bull Wharf Lid. v. Goodman Bros., [1937] 1 K.B. 534; County of Carleton v. City of Otrawa, [1965] S.C.R. 663.

(1975), 57 D.L.R. (3d) 699 (Ont. C.A.). Cp. Clearwater Well Drilling Lid. v. Wiebe (1996), 148 N.S.R. (2d) 306, mother not liable for debts of son, an undischarged bankrupt.

Cp. the question of intention to contract where it is alleged that a contract exists between the parties: on which see G.H.L. Fridman, Law of Contract, 3d ed. (Toronto: Carswell, 1994) at 26-31 [hereinafter Fridman, Law of Contract].

Magical, supra note 5. Cp. with respect to expectation of payment for work done: Hussey Seating Co. (Canada) v. Ottawa (City) (1997), 32 O.R. (3d) 633 (Gen. Div.). See also as to extra work Peter Kiewit Sons v. Eakins Construction Ltd., [1960] S.C.R. 361; Turf Masters Landscaping Ltd. v. T.B.G. Developments Lid. and Dartmouth (City) (1995), 143 N.S.R. (2d) 275 (C.A.) [hereinatter Turf].

But see $R$. v. Ron Engineering \& Construction (Eastern) Lid., [1981] 1 S.C.R. 111, on the possibility of an independent contract arising from the submission of a tender: on which see Fridman, Law of Contract, supra note 43 at 35-39. 
more and more this has been regarded by Canadian courts as entailing an obligation on the man to compensate the woman for her services. ${ }^{46}$

Secondly, according to the Nicholson case, there must be what was termed "a special relationship" between the parties. In a later case, Carabin v. Offman ${ }^{47}$ it was said that such a relationship had to be contractual, fiduciary or matrimonial. It has also been said that such a relationship has two characteristics: (1) knowledge of the benefit by the defendant; and (2) an express or implied request from the defendant for such benefit or acquiescence in its conferral. An express request may be proved by the existence of a contract that is unenforceable, invalid or otherwise not capable of supporting an action for breach of contract. An implied request may be implied from the circumstances (just as a contract may also be implied from the circumstances). Acquiescence seems to refer to something akin to estoppel. Whether estoppel may be invoked to establish the existence of a contract is a highly debated issue. But there seems to be no doubt that estoppel may be invoked to establish quasi-contractual or restitutionary recovery. For this to result, the defendant must have encouraged or permitted performance of the work or services in question or must have stood by knowing that they were being performed and with the capacity to prohibit or ban their performance without doing anything to dissuade or prevent the plaintiff from acting.

In Carvery v. Fletcher, ${ }^{48}$ for example, the plaintiffs improved residential property which they believed, incorrectly as it turned out, they were purchasing from the defendant. The plaintiffs' claim for reimbursement succeeded. The defendant had allowed the plaintiffs to undertake the improvements although the defendant was under the belief that the contract between the parties was for the lease, not the sale of the property. Here the defendant was guilty of what was called "some wrongdoing." The contrary was the situation in Carabin v. Offman. ${ }^{49}$ A tenancy was involved: but it was never formally completed. Meanwhile the tenant altered the property to make it suitable for the martial arts business that was pursued on the premises. Because of the noise from that business the landlord, who occupied the premises below those leased to the plaintiff, cancelled the plaintiff's lease. No compensation was given to the plaintiff for the improvements. The plaintiff's claim was unsuccessful. The landlord had done nothing wrong: nor had the landlord been unjustly enriched by what the tenant had done. ${ }^{50}$ Nor was there any acquiescence, as in the Carvery case.

The comparison of these two cases highlights the distinction between restitutionary recovery based on receipt of a benefit and such recovery stemming from acquiescence or estoppel which does not seem to require that the defendant receive any benefit. Thus in Estok v. Heguy ${ }^{51}$ and Preeper v. Preeper ${ }^{52}$ recovery was allowed in respect of socalled "improvements" to land which the plaintiff believed was, or was about to

4 Pettkus, supra note 31; Sorochan v. Sorochan (1986), 29 D.L.R. (4th) I (S.C.C.).

47 (1989), 55 D.L.R. (4th) 135 at 149 (N.S.S.C.A.D.).

48 (1987), 76 N.S.R. (2d) 307 (S.C.T.D.).

49 (1988), 84 N.S.R. (2d) 76 (N.S.S.C.T.D.).

so Turf, supra note 44; see also Captial Construction, supra note 3.

s1 (1963), 40 D.L.R. (3d) 88 (B.C.S.C).

s2 (1978), 84 D.L.R. (3d) 74 (N.S.S.C.T.D.). 
become his, even though the changes made by the plaintiff were of no utility to the defendant, because, in both instances, the defendant had stood by and made no objection when the plaintiff made the improvements. Thus, although it is sometimes stated that recovery depends on whether the defendant received any benefit from what was done by the plaintiff, this does not always seem to be crucial. Indeed if a benefit has been conferred on the defendant this would appear not to suffice to ground recovery by the plaintiff in the absence of the essential elements of request or acquiescence, both of which entail knowledge on the part of the defendant in advance of what is done by the plaintiff. ${ }^{33}$

\section{The Peel CaSe}

A contrary view seems to have been stated by McLachlin J. in Peel (Regional Municipality) v. Canada; Peel (Regional Municipality) v. Ontario. ${ }^{54}$ The issue there was whether recovery could be obtained in respect of payments made by the Peel municipality under the mistaken belief that the law obliged it to contribute to the support of a juvenile delinquent. After such payments had been made the Supreme Court of Canada held that the statutory provision under which they had been made ${ }^{55}$ was ultra vires the federal Parliament. ${ }^{56}$ The municipality sued both the federal and provincial governments for the return of the money it had expended. At trial both actions succeeded, only to be reversed by the Ontario Court of Appeal and the Federal Court of Appeal. The municipality's appeals to the Supreme Court of Canada also failed. That court held that since the municipality had not discharged any legal liability of the provincial and federal governments, the latter had not been benefited by what had been done by the municipality. Ergo this was not a suitable case for restitutionary recovery.

This conclusion was based upon the determination by McLachlin J. that "at the heart of the doctrine of unjust enrichment, whether expressed in terms of the traditional categories of recovery or general principle" (the distinction between which her Ladyship had considered earlier in her judgment ${ }^{57}$ ) "lies in the notion of restoration of benefit which justice does not permit one to retain." given, whether goods, services or money. The thing which is given must have been received and retained by the defendant. And the retention must be without juristic justification. ${ }^{59}$ She went on to say later:

See Airport Nissan Lid. v. Wilson (1986), 17 C.C.L.I. 131 (Ont. Dist. Ct.) with which compare the famous, or infamous English case of Greenwood v. Bennett, [1973] 1 Q.B. 195 (C.A.), where Lord Denning M.R., but not the other two members of the court, invoked the law of restitution. The case has been the subject of much academic discussion: but the point in issue is now dealt with by the Torts (Interference with Goods) Act 1977 (c. 32).

Supra note 33.

Ibid. at 154.

59 Ibid., quoting Dickson J. in Pettkus v. Becker, supra note 31 at 273-74. 
The word 'restitution' implies that something has been given to someone which must be returned or the value of which must be restored by the recipient. The word 'enrichment' similarly connotes a tangible benefit. It follows that without a benefit which has 'enriched' the defendant and which can be restored to the donor in specie or by money, no recovery lies for unjust enrichment.

In relation to cases of payment under compulsion of law, establishment of "benefit" meant proof that the plaintiff's payment discharged the defendant's liability. This the municipality could not show. There was no constitutional obligation on any government, federal or provincial, to provide for the care of the juvenile delinquents: nor was there any statutory or legal liability on such governments to do this. Provincial governments had a discretion to finance the acquisition or construction of institutions for the care of the children in question, or to finance the operation of such institutions. The benefit received by the federal government was the care of "prisoners" which the federal government might have had to provide itself: and a more general "political" benefit. The provincial government might have received the benefit of the discharge of responsibilities it might have undertaken. But neither government was relieved of a legal liability by what the municipality had done.

So the municipality argued that the test of recovery could be met if what it had done had discharged a political, social or moral responsibility of the provincial governments. This required McLachlin J. to consider the definition of "benefit" in the general test for recovery for unjust enrichment. This led to a discussion of the notion of "incontrovertible benefit." McLachlin J. does not seem to have embraced or endorsed this idea with any enthusiasm. But, even if, as she said, the law of restitution should be extended to incontrovertible benefits, the municipality fell short of the law's mark. ${ }^{62}$ The benefit conferred did not come within the definitions of incontrovertible benefit proposed by various writers referred to and considered by McLachlin J. To allow recovery in this instance would extend the concept of benefit in the law of unjust enrichment further than contemplated by authorities to date. It would take the law of unjust enrichment far beyond the concept of restoration of property, money or services unfairly retained, which lies at its core. ${ }^{63}$

It is this insistence on the vital importance of a benefit in order to justify restitutionary recovery in this instance that makes the judgment in this case questionable. This was not a quantum meruit action in which a plaintiff was seeking to recover the value of services performed in anticipation of a contract, whether in the belief that a contract existed, or for any other reason as a result of which quantum meruit claims have been held in Canada to justify recovery on the basis of unjust enrichment or restitution. The Peel case centred on an alleged compulsory discharge by one party of another party's legal liability. The real question was whether any such legal liability had been discharged. By her analysis and reading of the relevant legislation the learned judge proved that this had not happened. Hence, the plaintiff's

Supra note 58 at 155.

lbid. at 158-60.

lbid. at 160-61.

Ibid. at 161. 
case deservedly failed. Although McLachlin J. sought to generalize, or bring together disparate instances of restitutionary recovery, by her discussion of the various classes of traditional recovery and the general principles of restitution, this approach was unnecessary for the decision and fundamentally wrong. The category of restitutionary recovery into which the fact-situation in the Peel case fell was not one that related to the situations to which reference has been made herein in which quantum meruit recovery has been granted. Hence her remarks about "benefit," it is suggested, should be regarded as obiter, indeed as incorrect, insofar as they purport to relate to quantum meruit recovery as considered herein.

\section{CONClusion}

The Peel case illustrates the essential issue in the law of unjust enrichment or restitution: namely, whether there are what McLachlin J. termed "classes of traditional recovery" or "general principles of restitution," a debate that resembles the age-old discussion whether there is a law of torts or a law of tort, or the issue raised by Gilmore in The Death of Contract, whether there is a law of contract or only law relating to different kinds of contract. In a sense this kind of debate is jejeune and unrewarding. However, beneath any such debates lurks another, and more important question: whether law should be based upon firm, settled doctrines that not only explain existing instances of liability or recovery but also provide the method and reasoning capable of determining novel situations when they present themselves for decision by courts. Does it come down to a choice between what McLachlin J. called" "inflexible rules" and "case-by-case 'palm-tree justice'?"

If that is indeed the choice the present writer would prefer inflexible rules. But, in point of fact, as every common lawyer knows, there are no "inflexible" rules. The doctrine of precedent, as developed in the common law world, permits rules to be inflexible, or, to put this another, and better way, allows the evolution and development of rules gradually and by a process of pragmatic resolution. As far as restitutionary quantum meruit recovery is concerned, as discussed by the present writer here and elsewhere, ${ }^{65}$ this has been done in Canada without the necessity for speaking in terms of irrebuttable or incontrovertible benefit or so-called free acceptance. It would be reactionary and restricting now, it is suggested, to jeopardize what has been achieved in Canada, where the law has evolved in a manner that has not occurred in England or Australia, by the kind of reasoning and arguments contained in the judgment of McLachlin J. in the Peel case. There, as previously argued, confusion reigned. It is to be hoped that, as and when occasion arises, the Supreme Court will take the opportunity to recognize and declare that where quantum meruit is involved the bases of recovery may not be the same as in other situations where the common law in Canada has permitted a plaintiff to succeed in an action for unjust enrichment or restitution. 